\title{
INFORMED CONSENT ON THERAPEUTIC TRANSACTION AS A PROTECTION OF LEGAL RELATIONSHIP BETWEEN A DOCTOR AND PATIENT
}

\author{
Dian Ety Mayasari* \\ Civil Law Departement, Faculty of Law Universitas Katolik Darma Cendika \\ Jalan Dr. Ir. H. Soekarno No. 201 Surabaya, Jawa Timur 60117
}

\begin{abstract}
Consent of the patient or the patient's family is needed before a medical treatment performed by a doctor. Beforehand, the patient or the patient's family calls for a piece of information from the doctor or so-called informed consent related to the medical measures. The therapeutic transactions conducted by the doctors may occur after the informed consent is received by the patient. It becomes $a$ part of the Civil law because the therapeutic transaction is based on an agreement that gives rise to the rights and obligations of the doctor and patient as outlined in Article 1330 Indonesia Civil Code (KUHPerdata).
\end{abstract}

Keywords: doctor, patient, medical action.

\section{Intisari}

Persetujuan pasien atau keluarga pasien sangat dibutuhkan dokter sebelum dilakukannya tindakan medis oleh dokter, namun sebelumnya pasien atau keluarga pasien membutuhkan informasi dari dokter atau disebut informed consent terkait tindakan medis tersebut. Transaksi terapeutik yang dilakukan dokter bisa terjadi setelah informed consent diterima oleh pasien. Hal ini menjadi bagian dalam hukum Perdata karena terjadinya transaksi terapeutik berdasarkan dari perjanjian yang akhirnya menimbulkan hak dan kewajiban pada dokter dan pasien sebagaimana diatur dalam Pasal 1330 KUHPerdata.

Kata Kunci: dokter, pasien, tindakan medis.

\section{Pokok Muatan}

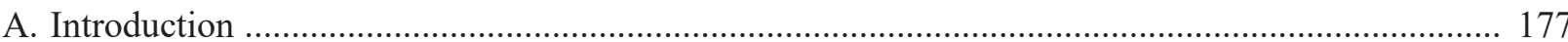

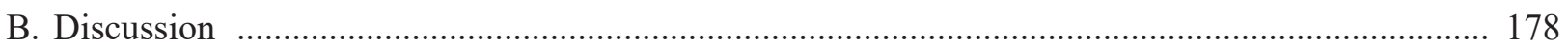

1. Definition of The Informed Consent and Therapeutic Transaction ......................................... 178

2. The Relationship Informed Consent and Therapeutic Transaction in Civil Law ....................... 180

3. The Protection of the Rights and Obligations of the Doctors and Patients After the Informed Consent in A Therapeutic Transaction ....................................................................................... 183

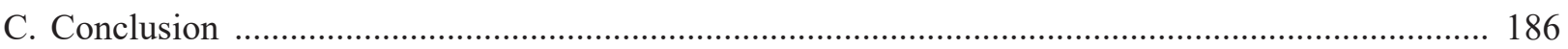




\section{A. Introduction}

Health is an important part of human life to be able to perform activities. As has been regulated in Article 1 paragraph (1) of Law No. 36 of 2009 on Health (the Law on Health), Health is a healthy condition, whether it is physical, mentally, spiritually or socially which enable every person to have a productive life socially and economically. ${ }^{1}$ However, it cannot be denied that weak physical condition, dietary habit, high volume of work, and the lack of rest make someone unwell, or unaware of his condition. Someone who is suffering from a sickness surely does not possible to perform his best productive activities for himself, his family or other people. Article $28 \mathrm{H}$ of the 1945 Indonesian Constitution stipulates that every person shall have the right to live in physical and spiritual prosperity, to have a home and to enjoy a good and healthy environment, and shall have the right to obtain health care. ${ }^{2}$ It can be clarified that the stipulation of such Article 28 H The 1945 Indonesian Constitution requires the availability of health care as a right for every person.

Health care according to the provisions of the Law on Health divided into 5 (five), namely promotive health care, preventive health care, curative health care, rehabilitative health care, and traditional health care. The elaboration of those 5 (five) kinds of health care is regulated in Article 1 paragraph (12) until (16) of the Law on Health. ${ }^{3}$ The promotive health care as has been regulated in Article 1 paragraph 12 of the Law on Health is an activity and/or a set of activities of health care that emphasizes to the promotional activities. ${ }^{4}$ Preventive health care according to Article 1 paragraph 13 of the Law on Health is a prevention activity towards a medical problem/sickness. ${ }^{5}$ The definition of curative health care in Article 1 paragraph 14 of the Law on Health is an activity and/or a set of treatment activities purposed for healing, reducing the pain because of the disease, disease control, or defect control so that the quality of the patient can be maintained in the best condition. ${ }^{6}$ Article 1 paragraph (15) of the Law on Health stipulates that rehabilitative health care is an activity and/or a set of activities to return the former patient to the society so that he can work again as the member of the community who is useful as maximum as possible for himself and the society in accordance with his capability. ${ }^{7}$ Whereas the definition of traditional health care in Article 1 paragraph (16) of the Law on Health is a treatment and/or medication through procedure and medicine which refer to empirical hereditary experience and skill that can be accounted for and applied in accordance with the applicable norms in the society. ${ }^{8}$ To make the health care works effectively, it is necessary to have health care facilities and health workers to support the health care services. Article 1 paragraph (7) of the Law on Health explains the meaning of health care facilities as a tool and/or place which is used to perform the health care services, whether it is promotive, preventive, curative, or rehabilitative which is done by the Government, the regional government, and/or the society. ${ }^{9}$ What is meant by the health worker in Article 1 paragraph 6 of the

Article 1 paragraph (1) of Law No. 36 of 2009 on Health (State Gazette of The Republic of Indonesia Year 2009 Number 144, Supplement to State Gazette of The Republic of Indonesia Number 5063).

Article 28 H Indonesia Constitution 1945.

Artilce 1 parapraph (12) until paragraph (16) of Law No. 36 of 2009 on Health (State Gazette of The Republic of Indonesia Year 2009 Number 144, Supplement to State Gazette of The Republic of Indonesia Number 5063).

4 Article 1 paragraph (12) of Law No. 36 of 2009 on Health (State Gazette of The Republic of Indonesia Year 2009 Number 144, Supplement to State Gazette of The Republic of Indonesia Number 5063).

Article 1 paragraph (13) of Law No. 36 of 2009 on Health (State Gazette of The Republic of Indonesia Year 2009 Number 144, Supplement to State Gazette of The Republic of Indonesia Number 5063).

Article 1 paragraph (14) of Law No. 36 of 2009 on Health (State Gazette of The Republic of Indonesia Year 2009 Number 144, Supplement to State Gazette of The Republic of Indonesia Number 5063).

Article 1 paragraph (15) of Law No. 36 of 2009 on Health (State Gazette of The Republic of Indonesia Year 2009 Number 144, Supplement to State Gazette of The Republic of Indonesia Number 5063).

Article 1 paragraph (16) of Law No. 36 of 2009 on Health (State Gazette of The Republic of Indonesia Year 2009 Number 144, Supplement to State Gazette of The Republic of Indonesia Number 5063).

Article 1 paragraph (7) of Law No. 36 of 2009 on Health (State Gazette of The Republic of Indonesia Year 2009 Number 144, Supplement to State Gazette of The Republic of Indonesia Number 5063). 
Law on Health is every person who devoted himself in the health sector and has experience and/or skill that he obtains through education in health area which is in certain categories require an authority to perform a medical effort. ${ }^{10}$ One of the health workers is a doctor, where a doctor in performing a medical treatment or medical practice is purposed to perform a medical effort. A medical effort according to Article 1 paragraph (11) of the Law on Health is every activity and/or a set of activities done integrally, integrated and continuous to maintain and advance the people's health standard in the form of prophylaxis, health improvement, disease treatment and health recovery by the government and/or the society. ${ }^{11}$

To further regulate the doctor activities in medical effort and as a form of protection and to give legal certainty to the doctors, Indonesian Government has enacted the Law No. 29 of 2004 on Medical Practice (the Law on Medical Practice). The definition of medical practice performed by a doctor is stipulated in Article 1 paragraph (1) the Law on Medical Practice as a set of activities performed by a doctor and a dentist towards a patient in performing a medical effort. ${ }^{12}$ To make his skill to be acknowledged, a doctor shall pass a competence test and holds a competence certificate as a prove. After obtaining a competence certificate, a doctor who wants to perform a medical practice should have a practice permit issued by the government or in this case issued by an authorized medical officer in the municipality (kabupaten) where such medical practice is performed.

A patient and the patient's family give their trust to a doctor to perform a medical effort to recover the patient. It is unfortunate when a doctor has made every effort to cure a patient, but the future holds differently as the patient is not cured or died and the doctor is put into blame since the patient is not cured because of his negligence.

The focus of this writing is not the negligence of a doctor in giving information regarding the worst possibility if a surgery or his action in order to cure the patient is unsuccessful, including the possibility of the patient's death, but the importance of the informed consent is prior to the therapeutic transaction performed by the doctor to his patient so that each of the parties understand his rights and obligations.

\section{B. Discussion}

\section{Definition of The Informed Consent and Therapeutic Transaction}

According to Bambang Poernomo, what is meant by an informed consent is the presence of a consent arising from information which is considered clear by a patient towards a medical action that will be performed to him for a diagnose and/or a health therapy. ${ }^{13}$ J. Guwandi divides the informed consent into two forms, namely:

a. Expressed Consent

1. Orally;

2. Written.

b. Implied or Tacit Consent

1. normal or constructive consent;

2. emergency. ${ }^{14}$

The regulation regarding the informed consent is stipulated in Article 45 of the Law on Medical Practice. However, as an implementation of such article, as has been stated on its consideration, the Minister of Health has issued the Minister of Health Regulation No. 290/MENKES/PER/III/2008 on the Approval of Medical Action in which its Article 1 paragraph (1) gives a definition of the informed consent as a consent given by a patient or his closest family after obtaining a complete explanation

10 Explanation article 1 paragraph (6) of Law No. 36 of 2009 on Health (State Gazette of The Republic of Indonesia Year 2009 Number 144, Supplement to State Gazette of The Republic of Indonesia Number 5063).

11 Article 1 paragraph (11) of Law No. 36 of 2009 on Health (State Gazette of The Republic of Indonesia Year 2009 Number 144 , Supplement to State Gazette of The Republic of Indonesia Number 5063).

12 Article 1 paragraph (1) of Law No. 29 of 2004 on Medical Practice (State Gazette of The Republic of Indonesia Year 2004 Number 116, Supplement to State Gazette of The Republic of Indonesia Number 4431).

13 Bambang Poernomo, 1988, Hukum Kesehatan, Program Pasca Sarjana IKM Universitas Gajah Mada, Yogyakarta, p. 23.

14 J. Guwandi, 2006, Informed Consent dan Informed Refusal, Edisi VI, Balai Penerbit Fakultas Kedokteran Universitas Indonesia, Jakarta, p. 5. 
regarding the medical action or dentistry action that will be performed to the patient. ${ }^{15}$ Under this stipulation, it can be understood that the purpose of informed consent is to give a legal protection to the patient and the doctor. ${ }^{16}$ In other word, with the presence of the consent from the patient or the patient's family, thus a doctor can perform a medical action to the patient optimally; however for a high-risk medical action, it is necessary to have a written consent from the patient or the patient's family in order to avoid the doctor from the claim of any patient or his family if the medical action performed is unsuccessful.

The consent towards a doctor's medical action can be in verbal or written form. According to Amril Amri, there are 2 kinds of medical action consent, namely:

1. Implied consent

Generally, implied consent is given in a normal condition, meaning that the doctor can capture the consent to such medical action from a sign given/ showed by the patient. Likewise, in an emergency case, when a doctor needs an immediate medical action while the patient is not able to give consent and his family is not there; thus, the doctor can perform the best medical action according to him.

2. Expressed consent

It can be expressed verbally or in written. In a medical action, which is invasive and contains high risk, the doctor should obtain a written consent which is known in hospitals as the surgery permit. ${ }^{17}$

The urge to get this informed consent is for the interest and benefit of the patient, meaning that the doctor in his profession carrying out his duty to provide an honest information regarding the patient's condition which is the right of the patient as has been regulated in Article 5 of the Board of Indonesian Doctors Society (Ikatan Dokter Indonesia) Decision Letter No. 111/PB/A.4/02/2013 on the Implementation of Indonesian Doctors Code of Conduct. It is stipulated that every doctor's procedure or recommendation that may debilitate the psychological and physical endurance, shall obtain consent from the patient or his family and only given for the interest and benefit of such patient. ${ }^{18}$ After receiving an explanation from the doctor, the patient or his family can decide whether they are going to accept or refuse the medical action that will be performed by the doctor. ${ }^{19}$

The written consent from the patient or the family is essential if the medical action performed by the doctor contains a high risk. The most important and the primary thing of the informed consent is the consent from the patient and or his family after receiving the explanation from the doctor before the doctor performs a medical action. This explanation is not only related to the risk that will happen to the patient, but also the estimation of the cost, as has been regulated under Article 7 paragraph (3) of the Minister of Health Regulation No. 290/MENKES/ PER/III/2008 on the Approval of Medical. Action which stipulates that the explanation of the medical action at least shall cover: ${ }^{20}$
a. The diagnosis and the procedure of the medical action;
b. The purpose of the medical action performed;
c. The alternate action and its risk;
d. The risk and complication that may occur;
e. The prognosis of the performed medical action;

\footnotetext{
Consideration of the Minister of Health Regulation No. 290/MENKES/PER/III/2008 on the Approval of Medical Action.

16 H. Salim H.S. dan Erlies Septiana Nurbani, 2014, Perkembangan Hukum Kontrak Innominaat di Indonesia (Buku Kedua), Sinar Grafika, Jakarta, p. 44.

17 Amril Amri, 1997, Bunga Rampai Hukum Kesehatan, Widya Medika, Jakarta, p. 31

18 Article 5 of the Board of Indonesian Doctors Society (Ikatan Dokter Indonesia) Decision Letter No. 111/PB/A.4/02/2013 on the Implementation of Indonesian Doctors Code of Conduct.

19 Ibid

20 Explanation of Article 7 paragraph (3) of the Minister of Health Regulation No. 290/MENKES/PER/III/2008 on the Approval of Medical.
} 
f. Cost estimation.

A detailed explanation is the right of the patient and his family especially for them who are unfamiliar with the medical world, like what has been stated by Husein Kerbala that the informed consent covers two essential patient's rights in its relation with the doctor. Such rights are the right to obtain information and the right of consent. ${ }^{21}$ Informed consent is the right of the patient that becomes an obligation for the doctor to give a detailed explanation since the purpose of the informed consent is to protect the patient against all medical actions which is done without the knowledge of the patient and to give legal protection to the doctors against all unpredictable and negative implications, for instance regarding the risk of treatment which is unavoidable although the doctors have performed as maximum as possible and exercised his action in prudence and thorough manner. ${ }^{22}$

The therapeutic transaction which is done after the informed consent between the doctor and the patient is also related to the human rights, namely the right of self-determination. The patience of a doctor is needed in listening to the patient's complains about his pain, and afterward, the doctor can do an interview with the patient with a purpose to obtain information regarding: ${ }^{23}$

1. Overview of the illness being suffered;

2. The condition entirely;

3. The condition and the health of his family;

4. The explanation regarding the patient's habits which are related to his complaints.

According to Hermien Hadiati Koeswajdi, what is meant by a therapeutic transaction is a transaction to look for and to apply the most suitable therapy to heal the patient's disease performed by a doctor. ${ }^{24}$ Therapeutic transaction between the doctor and the patient resulted in a legal relationship between the doctor and the patient, included the relationship in performing service as has been regulated under Article 1601 Indonesian Civil Code (KUHPerdata), where a doctor as a party who gives a medical care service, performs a medical action to the patients as the recipient of such medical care service. Therapeutic transaction acts as a law for the patient or the doctor as the parties, in which the law obliges the parties to fulfill their respective rights and obligations in accordance with the agreed stipulation. ${ }^{25}$

Veronica Komalawati argues that therapeutic transaction is a relationship between two legal subjects who bind themselves to each other based on trust. ${ }^{26}$ This means that the patient believes with all efforts made by doctors to cure the patient; thus the doctor has to maintain such patient's trust by performing an optimal medical action.

\section{The Relationship Informed Consent and Therapeutic Transaction in Civil Law}

The informed consent and therapeutic transaction become a unity that cannot be separated. This is because the therapeutic transaction only then occurs after there is consent from the patient or the patient's family based on the medical action information which will be performed by the doctor. Article 45 paragraph (1) of the Law on Medical Practice determines that every medical action or dentistry action which is conducted by a doctor or a dentist towards a patient shall obtain consent. ${ }^{27}$

The informed consent becomes the primary key of a doctor in performing a medical action, from this informed consent the patient or the patient's family will give their consent. The patient before

\footnotetext{
Husein Kerbala, 1993, Segi-Segi Etis dan Yuridis Informed Consent, Pustaka Sinar Harapan, Jakarta, p. 11.

J. Guwandi, Op.cit., p. 32.

Veronica Komalawati, 2002, Peranan Informed Consent Dalam Transaksi Terapeutik (Persetujuan Dalam Hubungan Dokter dan Pasien), Citra Aditya Bakti, Bandung, p. 147.

Hermien Hadiati Koeswadji, 1984, Hukum dan Permasalahan Medik, Bagian Pertama, Airlangga University Surabaya Press, Surabaya, p. 69. Anny Isfandyarie, 2006, Tanggung Jawab Hukum dan Sanksi Bagi Dokter (Buku Satu), Prestasi Pustaka, Jakarta, p. 69.

Veronica Komalawati, Op.cit., p. 141.

Article 45 paragraph (1) of Law No. 29 of 2004 on Medical Practice (State Gazette of The Republic of Indonesia Year 2004 Number 116, Supplement to State Gazette of The Republic of Indonesia Number 4431).
} 
giving their consent is needed to obtain several suggestions as follows: ${ }^{28}$

1. A complete explanation regarding the procedure that will be used in certain medical action (which is still an experiment) which is suggested by the doctor and the purpose that want to be achieved (the result of the experiment);

2. A description regarding the side effects and the unwanted implications that may occur;

3. A description regarding the benefits that may be obtained by the patient;

4. An explanation regarding the estimation period of the procedure;

5. An explanation regarding the right of the patient to withdraw his consent without any bad prejudice regarding his relationship with the doctor and his institution;

6. A prognosis regarding the medical condition of the patient if he refuses certain (experimental) medical action.

According to Leenen, in giving information, a doctor is also necessary to explain about the medical procedure and his experience in performing the medical action; regarding the risk of his medical action, a doctor is impossible to explain it in details, however explaining the general elements will be enough. Those elements are as follows: ${ }^{29}$

1. The nature;

2. The seriousness of the risk;

3. The probability of such risk;

4. The period of such risk to occur.

Article 45 paragraph (3) of the Law on Medical Practice determines that a complete explanation for a patient shall at least covers: ${ }^{30}$

1. The diagnosis and the procedure of medical action;

2. The purpose of the performed medical action;

3. The alternate action and its risk;
4. The risk and complication that may occur;

5. The prognosis of the performed medical action.

This relationship that occurs between the doctor and the patient is a legal relationship that happens because there is a trust from the patient or the patient's family to the doctor. The existence of such informed consent and therapeutic transaction makes the legal relationship between the doctor and the patient becomes a part of the coverage of Civil Law.

The reason why the relationship between the doctor and the patient becomes the part of the civil law is that there is an agreement between the doctor and the patient which then gives rise to the rights and obligations of the parties. According to Syahrul Machmud, what is meant by the civil relationship is a legal relationship conducted by parties who are in an equivalent position, at least when the parties are about to enter a certain legal relationship. ${ }^{31}$

The primary basis of this therapeutic transaction is because there is an agreement between the doctor and a patient. As has been regulated in Article 1313 of KUHPerdata, the definition of an agreement is an act in which one person or more binds himself to another person or more. Based on such definition, it is clear that a medical agreement occurs between a doctor and a patient. This agreement is considered valid as has been regulated in Article 1320 of KUHPerdata which shall fulfill the requirements: ${ }^{32}$

1. Consent to bind themselves;

2. Capability to conclude an obligation (perikatan);

3. A certain matter;

4. A lawful cause.

The first and the second requirements under

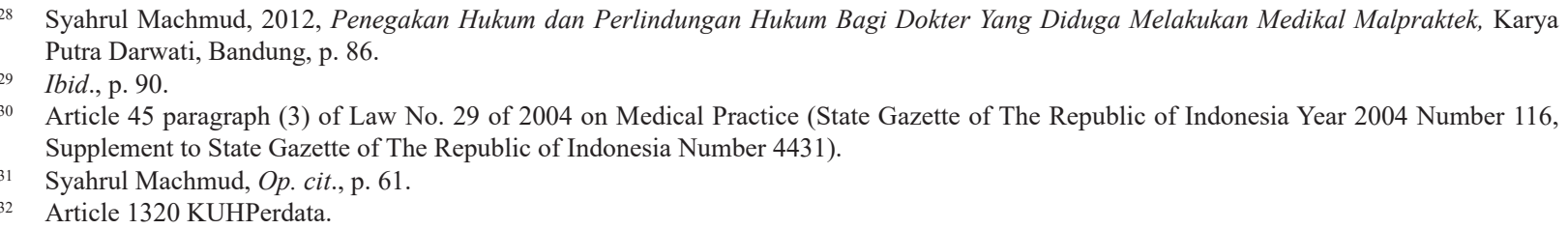


Article 1320 KUHPerdata are the subjective requirements, therefore if they are not fulfilled, it can be nullified. The third and fourth requirements of Article 1320 KUHPerdata are the objective requirements, therefore if they are not fulfilled, thus such agreement between the doctor and the patient is null and void.

The consent occurs based on the stipulation in Article 1321 KUHPer which says that no consent is valid if it is granted based on mistake or obtained by duress or fraud. According to Veronika Komalawati, the existence of consent is a conformity of the will. Therefore, based on consensual principle, for an occurrence of an agreement, the statement of conformity of will from each party is required. ${ }^{33}$ From the stipulation in Article 1321 KUHPerdata, it can be understood that there is no consent if consent is granted based on mistake or obtained by duress or fraud from one of the parties.

The capability requirement in the agreement making is based on the stipulation in Article 1329 and Article 1330 KUHPerdata. Article 1329 KUHPerdata determines that each person is authorized to conclude agreements unless he has been declared incapable by law. Article 1330 KUHPerdata regulates that persons who are incapable to conclude agreement are: ${ }^{34}$

1. minors;

2. those who are under guardianship;

3. married women, in the events stipulated by law, and in general, individuals who are prohibited by law from concluding specific agreements.

This third stipulation has been revoked through the Supreme Court Decree No. 3 of 1963 dated 4 August 1963 which contains the stipulation of Article 108 and Article 110 KUHPerdata regarding the authority of a married woman to perform a legal action and to appear before the court without additional permission from her husband is declared no longer effective.

In a therapeutic transaction, the recipient of the medical care consists of adults who are capable of performing an action, adults who are not capable of performing an action, who need consent from their guardians, children who are underage who need consent from their parents or their guardians. ${ }^{35}$

A certain matter in an agreement is regulated in Article 1333 KUHPerdata paragraph (1) An agreement must at least have as a subject a matter a property whose nature is determined; ${ }^{36}$ paragraph (2) The quantity of the matter needs not be ascertained, insofar such quantity can be determined or calculated at a later date. ${ }^{37} \mathrm{~A}$ certain matter in the agreement between the doctor and a patient is related to the object of the agreement, namely an effort to the healing process. According to Veronika Komalawati, the stipulation regarding the object of the agreement is strong related to the problem of the medical effort implementation which is in accordance with the standard of medical care that covers the illness care standard and the standard for supporting services and the information given shall not exceed from what is needed by the patient. ${ }^{38}$

Article 1337 KUHPerdata regulates that a cause is prohibited if it is prohibited by law, or if it violates morality or public order. ${ }^{39}$ Related to this lawful cause; thus all medical action which is conducted cannot be in contrary with the law, morality and public order. In performing a medical action which has high risk towards the patient's life, it is necessary to have provisions of a written agreement which is signed by the patient and one of the patient's family members as a form of consent and not merely verbally. It is purposed to protect the doctor if there is a medical action performed by him

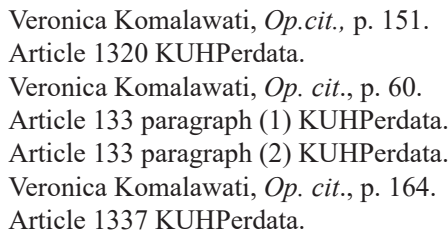


for his patient which is not successful as has been expected by the patient and his family; thus, this written agreement can release the doctor from all compensation claim from the patient and his family. This is in accordance with Article 3 paragraph (1) of Minister of Health Regulation No. 585/MEN.KES/ PER/IX/1989 which regulates that a certain medical action that has a high risk shall be performed with a written consent signed by the parties who give the consent. ${ }^{40}$

3. The Protection of the Rights and Obligations of the Doctors and Patients After the Informed Consent in A Therapeutic Transaction

The legal relationship between the doctor and the patient which is bound in a medical agreement is performed in an effort from the doctor to conduct a medical action for the recovery of the patient. In the contract law, there are two kinds of obligation (perikatan): ${ }^{41}$

1. Inspanningverbintenis (effort obligation/ perikatan usaha), is an agreement where each of the parties seeks or try as much as possible to actualize or produce an intended agreement or obligation (here the priority is the effort);

2. Resultaatverbintenis (result obligation/ perikatan hasil), is an agreement which is based on the agreed result or resultaat. Each of the parties tries as much as possible to produce or actualize what has been agreed (here the priority is the result).

In the case of medical action performed by a doctor for the recovery of the patient, it can be said that such relationship between the doctor and the patient is an effort obligation or perikatan usaha or inspanningverbintenis since the medical action performed by the doctor is based on the complain of the patient and based on the medical science, the doctor has conducted an effort to perform a medical action for the recovery of his patient.

The attachment of the doctor and the patient is based on consent in inspanningverbintenis which creates the rights and the obligations of the parties. Dany Wiradharma quotes Leenen's opinion, stated that the obligation of a doctor or a dentist in performing the medical care could be divided into three groups, namely: ${ }^{42}$

1. The obligation that arises from the nature of the medical treatment where the doctor shall act in accordance with medical profession standard or performing his medical practice in the way of lege artis;

2. The obligation to respect the patient's rights which are sourced from the basic human rights in health sector;

3. The obligation which is related to the social function of health care.

The rights and obligations of the patient and doctor have been regulated in the Law of Medical Practice, particularly in Article 50, 51, 51 and 53. A doctor or a dentist in performing a medical practice has rights as follows, as has been regulated in Article 50:43

a. Obtaining a legal protection as long as performing duty in accordance with the profession standard;

b. Providing a medical care in accordance with the profession standard and the operational procedure standard;

c. Obtaining a complete and honest information from the patient or his family;

d. Receiving incentives in exchange for services.

On the other hand, the obligations of a doctor

\footnotetext{
Article 3 paragraph (1) of Minister of Health Regulation No. 585/MEN.KES/PER/IX/1989.

Syahrul Machmud, Op. cit., p. 65.

Danny Wiradharma, 1996, Penuntun Kuliah Hukum Kedokteran, Bina Rupa Aksara, Jakarta, p. 74.

Article 50 of Law No. 29 of 2004 on Medical Practice (State Gazette of The Republic of Indonesia Year 2004 Number 116, Supplement to State Gazette of The Republic of Indonesia Number 4431).
} 
or a dentist as has been regulated in Article 51 of the Law on Medical Practice are: ${ }^{44}$

a. Providing medical care in accordance with the profession standard and the operational procedure standard as well as medical needs of the patient;

b. Referring the patient to another doctor or another dentist that has better skill or capability, in case he is not able to perform an examination or treatment;

c. Concealing everything that he knows about a patient, even after such patient deceased.

d. Performing an emergency aid for the sake of humanity, unless sure that there is another person in charge who is capable of doing it;

e. Increasing the knowledge and following the development of medical science or dentistry.

Under the Minister of Health Decision Letter No. 434 of 1983 on the Indonesian Doctors Code of Conduct, it is stipulated that a doctor has a set of obligations, namely general obligation, an obligation to the patient, an obligation to his colleagues, and obligation to himself. In the informed consent, it becomes an obligation of a doctor to the patient in terms of explaining to the patient or the patient's family regarding the sickness suffered by the patient based on the information or the patient's complaints and medical actions that will be performed by the doctors in his efforts to recover the patient.

The doctors' code of conduct which is a regulation in performing the profession of a doctor also regulates matters which are prohibited to be conducted by a doctor, namely: ${ }^{45}$

a. Conducting an action which is praising
himself;
b. Collaborating in giving all forms of
medical aid, without the freedom of
profession;
c. Receiving other money other than the reasonable incentive in accordance with his service, even though with the knowledge of the patient or his family. The rights of the patients in Article 52 of the Law on Medical Practice are: ${ }^{46}$

a. Obtaining a complete explanation regarding the medical action as has been stipulated in Article 45 paragraph (3);

b. Asking an opinion of a doctor or a dentist;

c. Obtaining a service in accordance with his medical needs;

d. Refusing a medical action; and

e. Obtaining the content of the medical record.

The rights of the patient are also regulated in the Indonesian Doctors Code of Conduct, namely:

1. Right to live, right to his body and right to die naturally;

2. Right to obtain a humane medical care according to the standards of medical profession;

3. Right to obtain explanation regarding the diagnosis and therapy from the doctor who treats him;

4. Right to refuse the diagnosis procedure and a planned therapy, the patient can even withdraw himself from the therapeutic contract.

5. Right to obtain an explanation regarding the medical experiment that he will follow and right to refuse or accept his participation in such medical experiment;

6. Right to be referred to a specialist if necessary, and returned to the referring doctor after the completion of consultation or medication to obtain treatment or follow-up;

7. Right to confidentiality or a personal medical record;

8. Right to obtain an explanation regarding the hospital regulation;

9. Right to contact with the family, counselors or clergy and others who

\footnotetext{
44 Article 51 of Law No. 29 of 2004 on Medical Practice (State Gazette of The Republic of Indonesia Year 2004 Number 116, Supplement to State Gazette of The Republic of Indonesia Number 4431).

45 Syahrul Machmud, Op. cit., p. 108.

46 Article 52 of Law No. 29 of 2004 on Medical Practice (State Gazette of The Republic of Indonesia Year 2004 Number 116, Supplement to
} State Gazette of The Republic of Indonesia Number 4431). 
are needed during the hospitalization;

10. Right to obtain explanation regarding the details of the cost of the hospitalization, medication, laboratory test, X-rays, ultrasonography (USG), CT-Scan, Magnetic Imaging (MRI) and so on, (if performed) the cost of the operating room, delivery room, the doctor's incentives in exchange for the services and others. ${ }^{47}$

The obligations of the patient in Article 53 of the Law on Medical Practice are:

a. Providing complete and honest information regarding his health problem;

b. Complying the advice and instructions of doctors or dentists;

c. Complying the applicable regulation in the health care facilities; and

d. Providing service incentives for the care that has been accepted.

Informed consent becomes the right of the patient because, in Article 7 of the Law on Health, it is regulated that every person is entitled to obtain a balanced and accountable information and education regarding health. ${ }^{48}$ Further regulation is in Article 8 of the Law on Health that every person has the right to obtain information regarding the data of his health included the medical actions and medications that have been or will be accepted from the medical workers. ${ }^{49}$

This protection towards the rights and obligations of the doctors and the patients is necessary because the medical profession is highly susceptible to the compensation claim addressed by the patient or the patient's family who feel that their rights are not fulfilled, particularly if attempts of medical actions performed by the doctor for the patient's recovery are not successful. Doctors are entitled to obtain legal protection and free from any claims for compensation if the doctor has performed the medical action in accordance with the procedure that has been established, in the sense that the doctor does not violate the operational procedure standard in the medical field.

According to Leenen, a medical action of a doctor is in accordance with the standards of the medical profession if it is done carefully in accordance with the medical standard as a doctor who has the average skill, compared with other doctors from the same skill category by means of a proportional effort compared with the concrete purpose of such medical action. ${ }^{50}$

The therapeutic transaction is started by the agreement between the doctor and the patient, therefore all this time, the filing of compensation claim which is the part of the civil law is always based on the occurrence of the breach of contract (wanprestasi) or tort (perbuatan melawan hukum). Wanprestasi or the breach of contract is based on the stipulation in Article 1239 KUHPerdata that every obligation to do something, or not to do something if the debtor fails to meet his obligations, is settled by way of compensation for costs, damages, and interests. In the civil law, someone is considered breached a contract or done wanprestasi if he: ${ }^{51}$

1. Does not perform what has been agreed to be done or does not perform the obligation (prestasi) at all;

2. Performs what has been agreed, but it is too late;

3. Performs what has been agreed, but does not in a way that has been agreed or the fulfillment of the obligation (prestasi) is not good;

4. Performs something that according to the nature of the agreement is not allowed to be done.

It is hard to prove that a doctor has breached a contract because the agreement between the doctor and the patient concluded in terms of the doctor

Syahrul Machmud, Op. cit., p. 114-115

Article 7 of Law No. 36 of 2009 on Health (State Gazette of The Republic of Indonesia Year 2009 Number 144, Supplement to State Gazette of The Republic of Indonesia Number 5063).

49 Article 8 of Law No. 36 of 2009 on Health (State Gazette of The Republic of Indonesia Year 2009 Number 144, Supplement to State Gazette of The Republic of Indonesia Number 5063).

50 Syahrul Machmud, Op. cit., p. 109.

51 Syahrul Machmud, Op. cit., p. 73. 
agrees to perform a medical effort for the recovery of the patient. Such effort can be preventive in terms of preventing other health problems that may be suffered by the patient or curative, namely performing a series of activities aimed at the healing treatment of disease, the reduction of the suffering caused by illness, disease control, or control of disability so that the quality of the patient can be maintained as optimal as possible. The medical action performed by the doctor has been adjusted with the medical science and the doctor's diagnose regarding the patient's illness has also been adjusted with the science that is studied. Therefore, if a doctor is alleged has breached a contract; thus, it is necessary to have verification from the doctor himself regarding the medical action that has been performed and its conformity with the procedure standard in the medical field.

If a doctor is claimed to have done a tort (perbuatan melawan hukum) as has been regulated in Article 1365 KUHPerdata that every unlawful act that causes damage to another person, obliges the wrongdoer to compensate such damage..$^{52}$ The explanation of Article 1365 KUHPerdata, a doctor can be said has done a tort (perbuatan melawan hukum) if the elements as follows are fulfilled: ${ }^{53}$

1. The act is an unlawful act;

2. There should be a fault;

3. There must be a loss inflicted;

4. There is a causality between the act and the loss.

If one of the elements is not fulfilled, thus a doctor cannot be said has done a tort. The element of fault and loss become a unity that cannot be separated, here there is a subject and object that should be proven. Subject means trying to see from the side of the doctor and object means trying to see the medical action performed by the doctor.

The tort (perbuatan melawan hukum) here means an unlawful act which is done by the doctor because it is in contradiction with the subjective right of the patient, for example as has been stated in Article 4 of the Law on Health, every person is entitled to health, thus in performing a medical action, a doctor shall prioritize the principle of prudence and thoroughness. This is in line with the opinion of Syahrul Machmud that what is considered as an unlawful act is when a medical action performed by a doctor or dentist is in contrary with his obligation, or breaching the subjective right of another person, or violate morality, or in contrary to the appropriateness principle, prudence and thoroughness that shall be owned by someone in association with the fellow resident or towards the assets of another person. This requirement is an alternative requirement, meaning that one requirement alone is enough to be considered as an unlawful act (perbuatan melawan hukum). ${ }^{54}$

To determine whether a doctor has done an unlawful act or not, it can be related with Article 1371 paragraph (1) KUHPerdata which regulates that a willful or negligent injury to any part of the body entitles the injured party to claim compensation for expenses incurred in the recovery caused by such injury or to claim additional compensation for expenses incurred because of such injury or disability. ${ }^{55}$ The vindication of such Article 1371 paragraph (1) KUHPerdata is located on the question of whether the injury or disability suffered by the patient is a result of the medical action performed by the doctor; therefore, if such vindication of the Article 1371 KUHPerdata is proven because of the negligence of the doctor, such doctor can be sued with the unlawful act (perbuatan melawan hukum) as has been regulated in Article 1365 KUHPerdata.

\section{Conclusion}

According to the explanation above, it can be concluded that the therapeutic action is started by the consent of the patient and the doctor. The

\footnotetext{
Article 1365 KUHPerdata.

Explanation of Aricle 1365 KUHPerdata.

Syahrul Machmud, Op. cit., p. 301.

Article 1371 paragrapah (1) KUHPerdata.
} 
consent between the patient and the doctor is in the form of an agreement inspanningverbintenis aside from the trust of the patient to the doctor surely the primary thing is the presence of informed consent. Informed consent becomes the most important part for the patient or the patient's family in deciding whether they want to allow, accept or refuse the procedure of medical action that will be performed by the doctor.

The doctor's therapeutic transaction is impossible to occur without the presence of an informed consent, unless if the patient comes by himself without any family, the patient is unconscious or in a high-risk condition and needs fast medical treatment thus a doctor should immediately take a medical action because if the doctor did not perform any action, it is the doctor himself that will be blamed because of his negligence of not giving a medical action.

The informed consent is absolute, becoming the right of the patient to obtain a clear and detailed medical explanation from the doctor and it is the obligation of the doctor so that a patient and the patient's family should know regarding his illness, the medicine and the recovery process or procedure that will be undertaken. Afterward, if there is consent from the patient and the patient's family regarding such medical explanation, then the doctor can perform the medical action.

The main understanding that this therapeutic transaction of the doctor and the patient becomes a part in inspanningverbintenis, not resultaatverbinten is based on the doctor's maximum effort as an actualization of his obligation with a purpose that the patient can recover, so the primary concern here is the maximum effort. This is based on the doctor who has tried based on the medical science that he has mastered, thus the proof if the patient does not get the desired recovery also requires medical research which is based on the medical science. The effort done by the doctor is not only based on the medical science that he mastered but must also adhere the principle of accuracy and prudence in every procedure performed by such doctor.

The legal protection for a doctor and a patient in the medical sector is primarily sourced from the informed consent; therefore, it is expected that giving clear and detailed information is not only the duty of the doctors but also the patients. The doctor is expected to have a good communication skill and patience to the patients and the patient's family since they who come to the doctor are unfamiliar with the medical science; thus, surely the doctor should be able to explain in details the illness of the patient until the patient and his family can understand it.

For the patient and the patient's family, they are expected to be honest regarding the illness suffered and if the explanation from the doctor is poorly understood by the patient and his family, they can ask the doctor including the estimation of the treatment cost that should be burdened, so that the patient and the patient's family do not hesitate to take a decision regarding the treatment for recovery. The informed consent is better to be done verbally and in written, which later signed by the patient and his family members as a prove of the agreement between the doctor and the patient so that the legal relationship between the doctor and the patient can be proven authentically.

\section{REFERENCES}

\section{A. Books}

Amri, Amril, 1997, Bunga Rampai Hukum Kesehatan, Widya Medika, Jakarta. Guwandi, J., 2006, Informed Consent dan Informed Refusal, Edisi VI, Balai Penerbit Fakultas Kedokteran Universitas Indonesia, Jakarta.
H.S., H. Salim, dan Nurbani, Erlies Septiana, 2014, Perkembangan Hukum Kontrak Innominaat di Indonesia (Buku Kedua), Sinar Grafika, Jakarta.

Husein Kerbala, 1993, Segi-Segi Etis dan Yuridis Informed Consent, Pustaka Sinar Harapan, 
Jakarta.

Isfandyarie, Anny, 2006, Tanggung Jawab Hukum dan Sanksi Bagi Dokter (Buku Satu), Prestasi Pustaka, Jakarta.

Komalawati, Veronica, 2002, Peranan Informed Consent Dalam Transaksi Terapeutik (Persetujuan Dalam Hubungan Dokter dan Pasien), Citra Aditya Bakti, Bandung

Koeswadji, Hermien Hadiati, 1984, Hukum dan Permasalahan Medik, Bagian Pertama, Airlangga University Surabaya Press, Surabaya.

Machmud, Syahrul, 2012, Penegakan Hukum dan Perlindungan Hukum Bagi Dokter Yang Diduga Melakukan Medikal Malpraktek, Karya Putra Darwati, Bandung Danny Wiradharma, 1996, Penuntun Kuliah Hukum Kedokteran, Bina Rupa Aksara, Jakarta.

Poernomo, Bambang, 1988, Hukum Kesehatan, Program Pasca Sarjana IKM Universitas Gajah Mada, Yogyakarta.

\section{B. Regulations}

Law No. 29 of 2004 on Medical Practice (State Gazette of The Republic of Indonesia Year 2004 Number 116, Supplement to State Gazette of The Republic of Indonesia Number 4431).

Law No. 36 of 2009 on Health (State Gazette of The Republic of Indonesia Year 2009 Number 144, Supplement to State Gazette of The Republic of Indonesia Number 5063).

The Minister of Health Regulation No. 585/MEN. KES/PER/IX/1989.

The Minister of Health Regulation No. 290/ MENKES/PER/III/2008 on the Approval of Medical Action.

The Board of Indonesian Doctors Society (Ikatan Dokter Indonesia) Decision Letter No. 111/ $\mathrm{PB} / \mathrm{A} .4 / 02 / 2013$ on the Implementation of Indonesian Doctors Code of Conduct.

KUHPerdata. 